Özlem İbrahimoğlu, Nevin Kanan

\section{The Effect of Progressive Muscle Relaxation Exercises After Endotracheal Extubation on Vital Signs and Anxiety Level in Open Heart Surgery Patients}

\author{
Açık Kalp Ameliyatı Olan Hastalarda, Endotrakeal \\ Ekstübasyon Sonrası Uygulanan Progresif Kas \\ Gevşeme Egzersizlerinin Yaşam Bulgularına ve Kaygı \\ Düzeyine Etkisi
}

Received/Geliș Tarihi : 09.01.2017 Accepted/Kabul Tarihi : 07.06.2017

${ }^{\circ}$ Copyright 2017 by Turkish Society of Intensive Care Turkish Journal of Intensive Care published by Galenos Publishing House.
Özlem Ibrahimoğlu

Bilecik Şeyh Edebali University Faculty of Nursing, Department of Surgery Nursing, Bilecik, Turkey

\section{Nevin Kanan}

Istanbul University Florence Nigtingale Faculty of Nursing, Department of Surgery Nursing,

Istanbul, Turkey

Özlem Ibrahimoğlu (困),

Bilecik Şeyh Edebali University Faculty of Nursing, Department of Surgery Nursing, Bilecik, Turkey

E-mail : oogutlu@gmail.com

Phone : +90 5436195971

ORCID ID: orcid.org/0000-0002-0925-0378
ABSTRACT Objective: The purpose of this study was to examine the effects of the exercises of progressive muscle relaxation (PMR) on vital signs and anxiety level after endotracheal extubation in open heart surgery.

Materials and Methods: This study was carried out as quasi-experimental, pre-test, and post-test with a control group. The study recruited 30 experimental and 30 control group open heart surgery patients, who met the inclusion criteria, from a cardiac and vascular surgery clinic of a university hospital. PMR exercises, which were taught before the surgery, were implemented after the surgery in the intensive care unit simultaneously with endotracheal extubation. The vital signs of the patients were monitored for the first $30 \mathrm{~min}$. The anxiety levels were measured after $30 \mathrm{~min}$ of extubation with state anxiety inventory.

Results: The lower rates of heartbeat, breathing, arterial blood pressure, and anxiety were observed in the experimental group in all measurements (first 30 min after endotracheal extubation), and the differences were statistically significant in favor of the experimental group $(p<0.05)$.

Conclusion: The study showed that the relaxation exercises after endotracheal extubation in open heart surgery patients was effective in improving vital signs and reducing anxiety level.

Keywords: Open heart surgery, progressive muscle relaxation, endotracheal extubation, anxiety level

ÖZ Amaç: Bu çalışma, açık kalp ameliyatı olan hastalarda endotrakeal ekstübasyon sonrası uygulanan progresif gevşeme egzersizlerinin (PGE) yaşam bulgularına ve kaygı düzeyine etkisini belirlemek amacıyla uygulandı.

Gereç ve Yöntem: Ön test - son test kontrol grup tasarımlı yarı deneysel bir çalışma olarak planlanan araştırma, bir üniversite hastanesinin kalp ve damar cerrahisi kliniğine açık kalp ameliyatı uygulamak için kabul edilen ve örneklem özelliklerini karşılayan 60 hasta (30 deney, 30 kontrol) ile gerçekleştirildi. Ameliyat öncesi öğretilen PGE, ameliyat sonrası dönemde yoğun bakım ünitesinde endotrakeal ekstübasyonla birlikte uygulanmaya başlandı. Hastaların yaşam bulguları ilk 30 dakika izlendi. Otuzuncu dakikada durumluluk kaygı düzeyi ölçüldü.

Bulgular: Endotrakeal ekstübasyon sonrası ilk 30 dakika süresindeki izlemlerinde, deney grubundaki hastaların arter kan basıncı değerleri, nabız hızı, solunum sayısı ve kaygı düzeyleri değerlerinin kontrol grubuna göre daha düşük olduğu ve aralarında deney grubunun lehine anlamlı farklıık olduğu saptandı $(p<0,05)$.

Sonuç: Açık kalp ameliyatı olan hastalarda endotrakeal ekstübasyon sonrası uygulanan progresif gevşeme egzersizlerinin yaşam bulguları ve kaygı düzeyi üzerine etkili olduğu bulunmuştur.

Anahtar Kelimeler: Açık kalp ameliyatı, progresif gevşeme egzersizleri, endotrakeal ekstübasyon, kaygı düzeyi 


\section{Introduction}

Cardiac surgery is used to correct and treat various cardiac disorders. It is done to revascularize the myocardium, repair or replace cardiac valves, repair ventricular aneurysm, remove heart tumors, manage heart trauma, and replace the heart with one from a human donor (1).

After open heart surgery using general anesthesia and cardiopulmonary bypass, the patient's respiratory function (vital capacity, total lung capacity, inspiratory capacity and functional residual capacity) is decreased; so after surgery patients are taken to intensive care unit for mechanical ventilation. Controlling tachycardia and hypertension which can occur due to catecholamine release from patients with endotracheal extubation, is important to protect myocardium and prevent potential complications (2-4).

Both intubation and extubation can increase the concentration of catecholamines in the blood by stimulating the sympathetic nervous system, and resulting in severe hemodynamic changes. However, during intubation, agents such as opioids and propofol can effectively inhibit airway stimulation by laryngoscopy and intubation. During extubation, the withdrawal of anesthetics and the emergence of patients from anesthesia stimulate the sympathetic nervous system, increasing the release of catecholamine and resulting in cough and hemodynamic responses, including hypertension and tachycardia. Although hemodynamic changes during this period are normally well-tolerated by healthy individuals, such changes may be detrimental in hypertensive patients, leading to lifethreatening complications such as myocardial ischemia, cardiac arrhythmias and cerebrovascular hemorrhage (3-6).

From research, Derbent et al. (7), reported that Wohlner in 1979 confirmed increases in heart rate, arterial pressure and vascular resistance that start some minute later after extubation and lasts 10 minutes; Dyson in 1990 reported that this increase in heart rate and arterial pressure is about $20 \%$ and is seen $70 \%$ of patients.

Progressive muscle relaxation (PMR), a method of relaxation techniques, include tension and relaxation muscles by unprompted, regularly and consecutively way until all body is relaxed. Progressive relaxation exercises were first developed in 1920's by Jacobson and then implemented into the technical science community by Hebert Benson. After long studies, progressive relaxation was accepted to be an effective technique in the control of muscular rigidity. This technique involves systematically stretching and relaxing the big muscle groups in human body. With PMR, the sympathetic nervous system tone decreases, and the parasympathetic nervous system increases, so the heart rate slows down, blood pressure drops, breathing rate decelerates, oxygen need decreases, metabolic rate slows down, pupils dilate, being peripheral dilatation and increasing peripheral heat, blood flow to big muscles increases, muscular rigidity, stress, fatigue and pain reduce and comfortable sleep is provided. It provides more energy and therefore more productivity in daily activities. Progressive relaxation enables to have a deep rest and a great refreshment, and almost a sense of rebirth (8-12).

PMR has become popular amongst psychologists and other health professionals during the last 30 years: as to nursing researches, firstly Aiken and Henrich's used systematic relaxation training as a nursing approach. From this research until today, it was found that nursing researcher used PMR in some chronic disease processes, preventing side effects of chemotherapy and dialysis, decrease the pain of patients on surgery and reduce the anxiety level of psychiatry patients, cardiac rehabilitation patients and university students (9-21).

Relying on these results, this study was carried out to determine the effect of PMR exercises applied after endotracheal extubation on vital signs and anxiety levels on patients with open heart surgery.

\section{Materials and Methods}

\section{Type of Research}

The research was conducted on patients who underwent open heart surgery as a quasi-experimental, pre-test and post-test with control groups. The research was carried out between April 2014-November 2014 and was initiated at department of cardiovascular surgery clinic and intensive care unit of one university hospital in Istanbul, Turkey.

\section{Population and Sample}

Sixty patients (30 exercise group, 30 control group) that were planned to undergo open heart surgery at department of cardiovascular surgery in an university hospital in Istanbul, accepted to be in research and suitable for content of research were included. According to inclusion criteria, patients that underwent surgical intervention like coronary artery bypass graft (CABG) surgery, valvular surgery or atrial septal defect (ASD)/ventricular septal defect (VSD) repair, over the 20 years of age, American Society of Anesthesiologists (ASA) $<4$ and 
EuroScore $<7$, can speak Turkish and planned endotracheal extubation within twelve hours after surgery, were included in research.

\section{Measurement and Instrument}

a. Personal information form: This form consists of 28 questions determining the socio-economic characteristics, type of operation, extubation times, pre and postoperative vital signs.

b. State-trait anxiety inventory: This inventory, which was developed by Spielberger in 1970, and adapted into Turkish by Öner and Le Compte (22), was used in order to evaluate the anxiety status of women. It consists of two separate inventories, each including 20 items. Each item in these inventories is graded from 1 to 4 , and the total score obtained for each inventory is at minimum 20 and maximum 80. High scores indicate a high level of anxiety.

\section{Performing Research}

After receiving necessary permissions, information about aim, content and method of research is given to the patients suitable for research during patient acceptance, and the sample group was formed by receiving permission from voluntary patients. The experimental and control groups were chosen at random. The day before surgery, PMR exercises were expressed to the experimental group through a one-onone training method. The distribution of sex and age were standardized as sexuality and age group would affect the results of research.

The day before surgery, patients' vital signs were measured. Data is collected from receiving intensive care unit to discharging from intensive care unit. In the experimental group, preparing equipment before endotracheal extubation, exercise is started by endotracheal extubation. PMR is performed through 30 minutes. During exercise, vital signs were recorded on structured patient information form at 1 st $2^{\text {nd }}, 3^{\text {rd }}, 5^{\text {th }}, 7^{\text {th }}, 10^{\text {th }}, 15^{\text {th }}, 20^{\text {th }}, 25^{\text {th }}, 30^{\text {th }}$ minutes. Patients in both group were applied state anxiety inventory to measure anxiety levels at $30^{\text {th }}$ minutes. Time of discharge from intensive care unit was recorded in both groups. In this study, Cronbach's Alpha Reliability Analysis was found 0.949.

\section{Ethical Permission}

Research was started after Clinical Studies Ethics Committee of Haydarpaşa Numune Training and Research Hospital (approval no: 2014/17, date: 24.02.2014) and written permission from the hospital where the research would be carried out. Related using the State Anxiety Inventory, verbal permission is received by N. Öner. Permission was also taken from the Turkish Psychological Association to use the "Relaxation Exercises CD" in the study (23). The patients, who were included in the research, were informed prior to data collection about the objective and duration of the research as well as the procedures to be performed during the research; they were told that they could withdraw from the research whenever they wanted and they were informed that their individual information would be preserved after being shared with the researcher.

\section{Data Analysis}

Data was coded and evaluated on computer using the NCSS and PASS statistical software. For evaluation of the data, percentage, arithmetic mean and standard deviation, chi-square, t-test in independent groups and matched t-test were used.

\section{Results}

The patients were predominantly male (experimental group $80 \%$, control group $76.7 \%$ ), the mean age of experimental group was $52.43 \pm 18.28$, and control group age was $57.57 \pm 16.62$ years, the mean body mass index (BMI) of experimental group was $27.03 \pm 4.63$ and the control group BMI was $28.10 \pm 3.78$, in experimental group $60 \%$ and in control group $66.7 \%$ were smokers, and just 3 patients $(10 \%)$ had a history of alcohol usage in two groups. No statistical differences were found between the two study group with demographic status and clinic specialty.

In experimental group, $23.3 \%$ of the patients were ASA 1, 30\% were ASA 2, 46.7\% were ASA 3. In control group, $13.3 \%$ were ASA $1,30 \%$ were ASA $2,56.7 \%$ were ASA 3. The patients were predominantly at low risk [0-3 points of Cardiac Risc Score (Euroscore) (experimental group 90\%, control group $76.7 \%)$ ] and the other remaining had moderate risk [4-6 points (experimental group 10\%, control group 23.3\%)]. No statistical differences were found between the two study group with ASA and Euroscore.

The operations were predominantly CABG (experimental group $53.3 \%$ and control group $80 \%$ ), valve surgery was at the second place (experimental group 20\% and control group $13,3 \%), A S D N S D$ repair surgery were a few (experimental group $13.3 \%$ and control group $6.7 \%$ ) and Bentall Procedure was held at only experimental group (13.3\%) (Table 1).

No statistical differences were found between two study groups regarding operating time, total bypass time, 
aortic cross-clamp time and hypothermia, but there were differences between two study groups regarding extubation time in the intensive care unit (ICU). It was found that the experimental group's extubation time was earlier than control group (Table 2).

There were no statistical differences between the groups with patient's vital signs before operation. Breathing rate and heart rate were found to be statistically significantly higher in the experimental group (Table 3).

During and after endotracheal extubation, patient's vital signs are presented in Table 4. During extubation, no statistical differences were found between the two study groups with patient's systolic-diastolic-mean arterial pressure, but statistical differences were found between the groups with only breathing rate and heart rate. The experimental group's respiration rate and heart rate was higher than the control group. It was considered that the experimental group patients get ready themselves to PMR which began to apply with endotracheal extubation.

When vital signs changing about pre-endotracheal extubation according to 1 st, $2^{\text {nd }}$, $3^{\text {rd }}$, $5^{\text {th }}$ minutes of postendotracheal extubation were examined, there were statistical differences between the groups. Changing of the experimental group's vital signs were lower than changing of the control group's vital signs. About $7^{\text {th }}, 10^{\text {th }}, 15^{\text {th }}, 20^{\text {th }}$, $25^{\text {th }}$, 30th minutes of post-endotracheal extubation were examined, there were statistical differences between the groups. The experimental group's vital signs were lower than the control group's vital signs (Table 4, Graphic 1).

The average state anxiety level in the experimental group was found $25.63 \pm 4.75$ and in the control group was found $39.20 \pm 10.09$ at $30^{\text {th }}$ minutes of post-endotracheal extubation. Statistical differences were found between the two study groups with state anxiety levels. The experimental group's state anxiety levels were lower than the control group ( $p=0.001, p<0.01$ ) (Table 5 ).

As shown in Table 6, the length of stay in intensive care unit in the experimental group was $1.20 \pm 0.40$ days, in the control group was $1.73 \pm 0.91$ days. There were statistical differences between the groups about length of stay in ICU. The experimental group's length of stay in ICU were lower than the control group's length of stay in ICU $(p=0.005$, $p<0.01$ ).

\section{Discussion}

Insertion and withdrawal of a laryngoscope and endotracheal tube during intubation and extubation can irritate the sympathetic nervous system, leading to severe tachycardia, hypertension or arrhythmia. Although the hemodynamic changes induced by general anesthesia are transitory and not harmful for healthy individuals, in

\begin{tabular}{|c|c|c|c|c|c|}
\hline \multirow{2}{*}{$\begin{array}{l}\text { Surgical } \\
\text { procedures }\end{array}$} & \multicolumn{2}{|c|}{ Experimental group $(n=30)$} & \multicolumn{2}{|c|}{ Control group $(n=30)$} & \multirow{2}{*}{$p$} \\
\hline & $n$ & $\%$ & $n$ & $\%$ & \\
\hline CABG & 16 & 53.3 & 24 & 80 & \multirow[t]{4}{*}{0.076} \\
\hline MVR/AVR & 6 & 20 & 4 & 20 & \\
\hline ASD/VSD & 4 & 13.3 & 2 & 6.7 & \\
\hline Bentall procedure & 4 & 13.3 & 0 & 0 & \\
\hline
\end{tabular}

Table 2. Comparison of the average operation characteristics and timing of extubation in experimental and control groups ( $\mathrm{n}=60$ )

\begin{tabular}{|c|c|c|c|c|c|}
\hline & \multicolumn{2}{|c|}{ Experimental group ( $n=30)$} & \multicolumn{2}{|c|}{ Control group ( $n=30$ ) } & \multirow{2}{*}{$P$} \\
\hline & Mean & SD & Mean & SD & \\
\hline Operation duration (h) & 6.52 & 1.38 & 6.90 & 1.18 & 0.253 \\
\hline Total bypass duration (min.) & 146.10 & 51.68 & 15.67 & 51.73 & 0.477 \\
\hline Aortic clamp duration (min.) & 88.53 & 38.06 & 88.00 & 34.31 & 0.955 \\
\hline Hypothermia $\left({ }^{\circ} \mathrm{C}\right)$ & 28.03 & 1.52 & 27.73 & 1.46 & 0.439 \\
\hline Intubation duration in ICU (h) & 7.78 & 1.79 & 8.88 & 2.04 & $0.031 *$ \\
\hline
\end{tabular}




\begin{tabular}{|c|c|c|c|c|}
\hline & & Experimental Group $(n=30)$ & Control Group $(n=30)$ & R \\
\hline & & Mean \pm SD & Mean \pm SD & $r$ \\
\hline & Preoperative & $134.13 \pm 20.40$ & $130.97 \pm 13.47$ & 0.481 \\
\hline & Before extubation & $133.20 \pm 13.42$ & $133.73 \pm 18.16$ & 0.898 \\
\hline 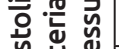 & $\mathrm{p}$ & 0.824 & 0.434 & \\
\hline ज它造 & Preoperative compared to before extubation (Median) & $-0.93 \pm 22.78(2.5)$ & $2.77 \pm 19.11(6)$ & 0.318 \\
\hline & Preoperative & $77.00 \pm 13.75$ & $71.57 \pm 11.33$ & 0.100 \\
\hline & Before extubation & $72.13 \pm 6.48$ & $71.33 \pm 9.33$ & 0.701 \\
\hline 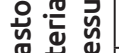 & $\mathrm{p}$ & 0.065 & 0.920 & \\
\hline 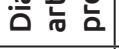 & Preoperative compared to before extubation (Median) & $-4.87 \pm 13.89(-1.5)$ & $-0.23 \pm 12.66(0.50)$ & 0.180 \\
\hline & Preoperative & $95.60 \pm 15.05$ & $89.93 \pm 13.02$ & 0.118 \\
\hline 岕 。 & Before extubation & $92.49 \pm 7.46$ & $92.13 \pm 10.62$ & 0.881 \\
\hline 赵 & $\mathrm{p}$ & 0.288 & 0.419 & 0.122 \\
\hline$\sum$ & Preoperative compared to before extubation (Median) & $-3.11 \pm 15.73(-0.5)$ & $2.30 \pm 15.37(5.17)$ & \\
\hline & Preoperative & $73.57 \pm 10.68$ & $72.60 \pm 1.95$ & 0.733 \\
\hline$\stackrel{\mathscr{\Perp}}{\mathrm{D}}$ & Before extubation & $91.93 \pm 13.36$ & $85.97 \pm 2.14$ & 0.071 \\
\hline 党 & $\mathrm{p}$ & $0.001 * *$ & $0.001^{* *}$ & \\
\hline$\stackrel{0}{I}$ & Preoperative compared to before extubation (Median) & $18.37 \pm 17.39(19.0)$ & $13.37 \pm 13.11(14.5)$ & 0.171 \\
\hline & Preoperative & $15.53 \pm 2.96$ & $14.80 \pm 2.63$ & 0.314 \\
\hline 苋 & Before extubation & $22.03 \pm 11.08$ & $16.20 \pm 3.58$ & $0.008 * *$ \\
\hline 总 & $\mathrm{p}$ & $0.001^{* *}$ & 0.076 & \\
\hline 商 & Preoperative compared to before extubation (Median) & $4.83 \pm 5.03(4.5)$ & $1.40 \pm 4.16(2)$ & $0.005^{* *}$ \\
\hline
\end{tabular}

Table 4. The results of patient's vital signs which across into and between the groups at during and first 30 minutes after endotracheal extubation (1st, $2^{\text {nd }}, 3^{\text {rd }}, 5^{\text {th }}, 7^{\text {th }}, 10^{\text {th }}, 15^{\text {th }}, 20^{\text {th }}, 2^{\text {th }}, 3^{\text {th }}$ minutes) $(n=60)$

\begin{tabular}{|c|c|c|c|c|c|c|c|c|c|c|}
\hline \multirow{3}{*}{ 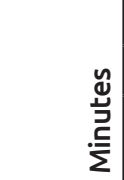 } & \multicolumn{10}{|c|}{ Vital Signs } \\
\hline & \multicolumn{2}{|c|}{ Sistolic (mmHg) } & \multicolumn{2}{|c|}{ Diastolic (mmHg) } & \multicolumn{2}{|c|}{ Mean $(\mathrm{mmHg})$} & \multicolumn{2}{|c|}{ Heart rate (/min) } & \multicolumn{2}{|c|}{ Respiration (/min) } \\
\hline & $\begin{array}{l}\text { Exp. } \\
\text { group }\end{array}$ & $\begin{array}{l}\text { Control } \\
\text { group }\end{array}$ & $\begin{array}{l}\text { Exp. } \\
\text { group }\end{array}$ & $\begin{array}{l}\text { Control } \\
\text { group }\end{array}$ & Exp. group & $\begin{array}{l}\text { Control } \\
\text { group }\end{array}$ & Exp. group & $\begin{array}{l}\text { Control } \\
\text { group }\end{array}$ & Exp. group & $\begin{array}{l}\text { Control } \\
\text { group }\end{array}$ \\
\hline Ext. & 133.20 & 133.73 & 72.13 & 71.33 & 92.49 & 92.13 & 91.93 & 85.97 & 20.36 & 16.20 \\
\hline 1. $\min$ & 133.90 & 158.10 & 73.27 & 81.00 & 93.48 & 106.70 & 95.70 & 96.03 & 20.90 & 23.37 \\
\hline 2. $\min$ & 134.17 & 154.47 & 73.37 & 78.83 & 93.63 & 104.04 & 93.23 & 96.23 & 19.97 & 23.43 \\
\hline 3. $\min$ & 133.17 & 152.50 & 73.27 & 78.40 & 93.23 & 103.10 & 92.73 & 95.70 & 19.40 & 22.57 \\
\hline 5. $\min$ & 131.07 & 148.47 & 71.97 & 76.00 & 91.67 & 100.16 & 93.17 & 95.43 & 18.73 & 22.80 \\
\hline 7. $\min$ & 129.03 & 146.27 & 70.87 & 75.90 & 90.26 & 99.36 & 92.37 & 94.30 & 19.27 & 21.97 \\
\hline 10. min & 129.23 & 145.33 & 69.73 & 74.80 & 89.57 & 98.31 & 92.10 & 94.83 & 19.10 & 21.30 \\
\hline 15. $\min$ & 126.93 & 144.80 & 69.07 & 74.57 & 88.36 & 97.98 & 92.30 & 94.87 & 18.43 & 21.53 \\
\hline 20. min & 125.97 & 142.30 & 68.00 & 73.20 & 87.32 & 96.23 & 92.63 & 93.76 & 18.40 & 20.73 \\
\hline 25. $\min$ & 124.93 & 140.00 & 67.90 & 72.13 & 86.91 & 94.76 & 91.10 & 93.70 & 18.30 & 20.50 \\
\hline 30. $\min$ & 126.47 & 138.37 & 68.00 & 71.83 & 87.49 & 94.01 & 91.90 & 93.97 & 18.37 & 19.80 \\
\hline
\end{tabular}


hypertensive patients they can lead to life-threatening complications, including myocardial ischemia and cardiac arrhythmias, and may even be fatal (3-6).

Non-pharmacological methods like different anesthetic techniques, extubation under deep anaesthesia, changing endotracheal tube with laryngeal mask, using special size endotracheal tubes, using lozenges, spray or mouthwash, daisy spray and acupuncture and pharmacological methods like both intravenous and topical anesthetics, alpha-beta adrenergic blockers, calcium-channel blockers, vasodilators and opioids have been used to stabilize hemodynamic responses during intubation or extubation, resulting in different side effects. Some of these side effects include increased sedation, difficulty in coughing and swallowing limit their use during extubation. Such complications may cause delayed discharge of the patient from the operating room or post anesthetic care unit. Care should be taken when using these agents, however, because of delays in postoperative awakening and the occurrence of complications associated with a decline in cardiac function (2-7,24-28).

The relaxation response limits the stress response, leading to reduced sympathetic nervous system tone. This action results in decreased muscle tension, oxygen consumption, blood pressure, heart and respiration rate (9$11,29,30)$.

\begin{tabular}{|c|c|c|c|}
\hline \multicolumn{4}{|c|}{$\begin{array}{l}\text { Table } 5 \text {. Comparison of the average State Anxiety Levels in } \\
\text { experimental and control groups at } 30^{\text {th }} \text { minutes of post- } \\
\text { endotracheal extubation }(n=60)\end{array}$} \\
\hline Test & $\begin{array}{l}\text { Experimental } \\
\text { group }(n=30)\end{array}$ & $\begin{array}{l}\text { Control group } \\
(n=30)\end{array}$ & \multirow{2}{*}{$p$} \\
\hline & Mean \pm SD & Mean \pm SD & \\
\hline State anxiety & $25.63 \pm 4.75$ & $39.20 \pm 10.09$ & $0.001 *$ \\
\hline
\end{tabular}

\begin{tabular}{|c|c|c|c|c|c|}
\hline \multicolumn{6}{|c|}{$\begin{array}{l}\text { Table 6. Comparison of the average length of stay in intensive } \\
\text { care unit in experimental and control groups }(n=60)\end{array}$} \\
\hline \multirow[t]{2}{*}{$\begin{array}{l}\text { The length of stay } \\
\text { in ICU }\end{array}$} & \multicolumn{2}{|c|}{$\begin{array}{l}\text { Experimental } \\
\text { group }(n=30)\end{array}$} & \multicolumn{2}{|c|}{$\begin{array}{l}\text { Control } \\
\text { group }(n=30)\end{array}$} & \multirow{2}{*}{$\mathrm{P}$} \\
\hline & \multicolumn{2}{|c|}{$\begin{array}{l}\text { Mean } \pm S \mathrm{D} \\
\text { (Median) }\end{array}$} & \multicolumn{2}{|c|}{$\begin{array}{l}\text { Mean } \pm \text { SD } \\
\text { (Median) }\end{array}$} & \\
\hline \multirow[t]{2}{*}{ Days } & \multicolumn{2}{|c|}{$1.20 \pm 0.40(1)$} & \multicolumn{2}{|c|}{$1.73 \pm 0.91(2)$} & \multirow{5}{*}{$0.005^{*}$} \\
\hline & $n$ & $\%$ & $n$ & $\%$ & \\
\hline 1 day & 24 & 80 & 14 & 46.7 & \\
\hline 2 day & 6 & 20 & 12 & 40 & \\
\hline$>3$ day & 0 & 0 & 4 & 13.3 & \\
\hline
\end{tabular}

Literature survey did not reveal any studies that measure the efficiency of progressive relaxation exercises on the vital signs of patient with endotracheal extubation. However, studies carried out in different fields have proved progressive relaxation exercises to be effective in reducing vital signs. Chaudhuri et al. (31) in their study in 2004, examined the effect of PMR in young adults on cardiac and respiratory response to stress, and suggested that PMR help regulate heart rate and reducing blood pressure. Büyükyılmaz and Aştı (32) in patients with total hip or knee replacement surgery have applied PMR; vital signs of pulse, systolic and diastolic arterial pressure, respiratory rate values are lower than the control group, a significant difference was detected between them is very advanced statistical significance. Similarly, studies showed PMR effective in significantly reducing the number of breaths, heart rate, blood pressure, and stressed $(9,14,33-35)$.

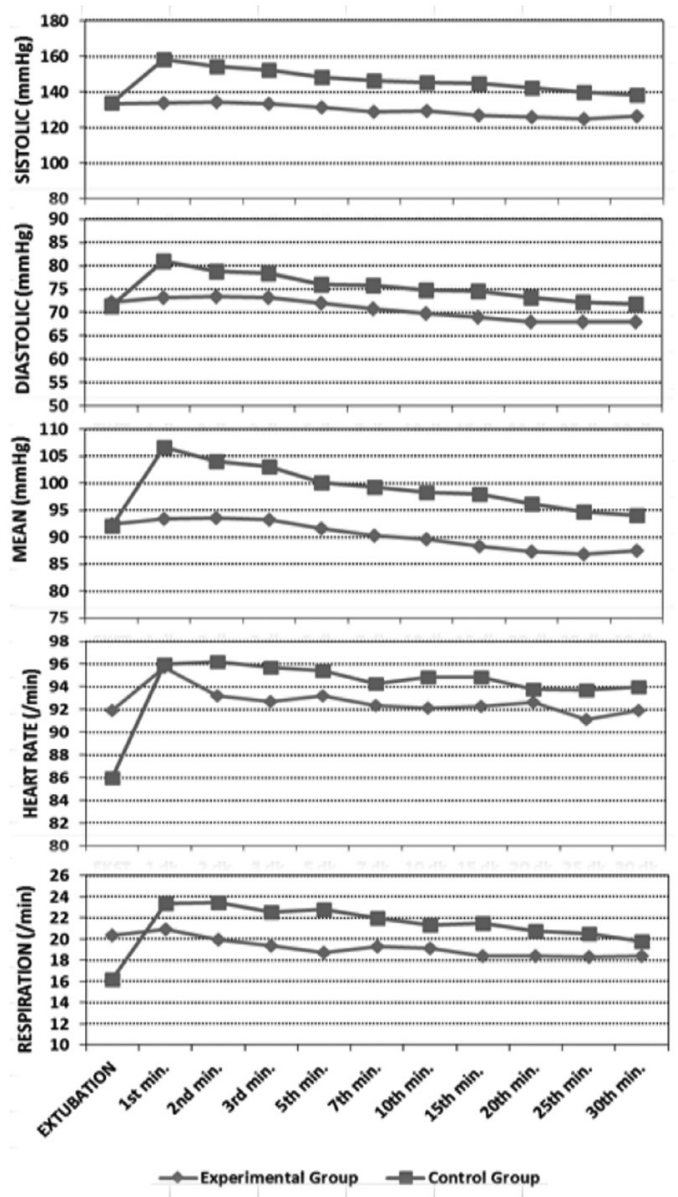

Graphic 1. The results of patient's vital signs which across into and between the groups at during and first 30 minutes after endotracheal extubation (15t $, 2^{\text {nd }}, 3^{\text {rd }}, 5^{\text {th }}, 7 t^{\text {th }}, 10^{\text {th }}, 15^{\text {th }}, 20^{\text {th }}, 25^{\text {th }}, 30^{\text {th }}$ minutes $)$ 
In this study, the heart rates, arterial blood pressure and respiratory rates values after endotracheal extubation at 1 st, $2^{\text {th }}, 3^{\text {th }}, 5^{\text {th }}, 7^{\text {th }}, 10^{\text {th }}, 15^{\text {th }}, 20^{\text {th }}, 2^{\text {th }}$ and $30^{\text {th }}$ minutes were significantly lower in experimental group when compared to control group (Graphic 1). After endotracheal extubation, hemodynamic response observed in experimental group was controlled less than control group, PMR reduce the influence of the sympathetic nervous system in controlling the metabolic responses seen after tracheal extubation, it could be used as an alternative treatment to help modulation of blood pressure and heart rate.

According to Gedik (36), as noted in the 2015 study, the time of surgery, duration, success rate, past medical problems, drainage, unknown devices such as catheters, medical procedures, pain after surgery, chills, disorientation, and being dependent and lifestyle changes, information requirements are among the causes of increasing concern. The state anxiety is used to condition characterized by clinically significant symptoms of anxiety, regardless of the circumstances and conditions in which the person shows up how they feel (37).

Studies carried out in different fields (stoma patients, patients receiving chemotherapy, dialysis and psychiatric patients, etc) have proved progressive relaxation exercises to be effective in reducing anxiety $(9,16-21,38-43)$. Dehdari et al. (44) applied to patients after CABG surgery studies of state and permanent PMR by reducing levels of anxiety reported that improve the quality of life.

In this study, it was determined that the patients in the experimental group had an average state anxiety level that was significantly lower than that of the control group (Table 1). The relaxation response, without tension or stress, provides mental and physical recovery. PMR affects patients' overall well-being and reduce anxiety in a positive way by supporting psychologically. In this study, the patients of PMR was found to be effective in reducing levels of trait state anxiety, and it has been found to be consistent with the literature.

In literature, after arriving to the intensive care unit, the patients were sent to the floor within 8 hours showed successful results. The general approach of patients within 24 hours after surgery, the average 15-20 hours in intensive care after being cared can be returned to service $(45,46)$. In this study, the clinical protocol should be applied in the clinic of the study, 7 days after open-heart surgery has been identified as the duration of hospitalization of patients. Therefore, patients in the experimental and control groups were examined only whether there were differences in the length of stay in the intensive care unit. Patients in the experimental group was determined to stay in the intensive care unit to be significantly shorter than the control group (Table 2).

PMR reducing pain and anxiety and reveal the emotional and physical well-being by increasing the self- sufficiency of patients, thus providing relief for the patient compliance to treatment and care/participation is emphasized that increase. The shorter duration of intensive care unit patients in the experimental group in this study strengthens the possibility that due to the effect of the progressive relaxation exercise.

\section{Conclusion}

PMR is a simple, non-invasive and cost effective method that can be used for promotion of the quality of life without any adverse effects. The effectiveness of the parasympathetic nervous system with PMR had a positive effect in reducing the anxiety and vital signs. In studies conducted to investigate the efficacy of pharmacological interventions to achieve similar results, the results of this study reinforce the possibility that due to the effect of the progressive relaxation exercise. In conclusion, in open heart surgery cases, PMR is found to be effective and can be useful to blunt the hemodynamic response to extubation which can also be harmful. Large scale randomized control studies are needed in order to provide sufficient evidence for the effectiveness of PMR for hemodynamic response to extubation after open heart surgery.

\section{Ethics}

Ethics Committee Approval: This study was approved by Clinical Studies Ethics Committee of Haydarpaşa Numune Training and Research Hospital (approval no: 2014/17, date: 24.02.2014).

Informed Consent: Verbal and written consent was obtained from the participants.

Peer-review: Internally peer-reviewed.

\section{Authorship Contributions}

Surgical and Medical Practices: Ö.I., Concept: Ö.I., N.K., Design: Ö.I., N.K., Data Collection or Processing: Ö.I., Analysis or Interpretation: Ö.I., N.K., Literature Search: Ö.I., N.K., Writing: Ö.I., N.K.

Conflict of Interest: The authors declare that no conflict of interest.

Financial Disclosure: There was no financial support. 


\section{References}

1. Timby BK, Smith NE. Caring for clients undergoing cardiovascular surgery. In: Introductory Medical-Surgical Nursing. 8th ed. USA: Lippincott Williams \& Wilkins; 2003:499-511.

2. Elia S, Liu P, Chrusciel C, Hilgenberg A, Skourtis C, Lappas D. Effects of tracheal extubation on coronary blood flow, myocardial metabolism and systemic haemodynamic responses. Can J Anaesth 1989;36:2-8.

3. Akarca D, Ölmez Kavak G, Tüfek A, Çelik F, Karaman H, Baysal Yıldırım $Z$, et al. Comparison of efficacies of dexmedetomidine, esmolol and lidocaine on control of hemodinamic responses developing in endotracheal extubation. Firat Medical Journal 2011;16:110-4.

4. Bostan $\mathrm{H}$, Eroğlu A. Comparison of the clinical efficacies of fentanyl, esmolol and lidocaine in preventing the hemodynamic responses to endotracheal intubation and extubation. J Curr Surg 2012;2:24-8.

5. Lowrie A, Johnston PL, Fell D, Robinson SL. Cardiovascular and plasma catecholamine reponses at tracheal extubation. Br J Anaesth 1992;68:261-3.

6. Meng YF, Cui GX, Gao W, Li ZW. Local airway anesthesia attenuates hemodynamic responses to intubation and extubation in hypertensive surgical patients. Med Sci Monit 2014;20:151824.

7. Derbent A, Demirdağ K, Balcıoğlu T, Kurdoğlu E. The effects of lidocaine and diltiazem on hemodynamic changes durıng tracheal extubation. Ege Journal of Medicine 2002;41:233-6.

8. Pawlow LA, Jones GE. The impact of abbreviated progressive muscle relaxation on salivary cortisol. Biol Psychol 2002;60:1-16.

9. Sheu S, Irvin BL, Lin HS, Mar CL. Effects of progressive muscle relaxation on blood pressure and psychosocial status for clients with essential hypertension in Taiwan. Holist Nurs Pract 2003;17:41-7.

10. Özveren H. Non-Pharmacological Methods at Pain Management. Hacettepe University Faculty of Health Sciences Nursing Journal 2011;83-92.

11. Demiralp M, Oflaz F. Cognitive behavioral therapy techniques and psychiatric nursing practice. Anatolian Journal of Psychiatry 2007:8:132-9.

12. Özdemir F, Pasinlioğlu T. The effects of training and progressive relaxation exercises on anxiety level after hysterectomy. The New Journal of Medicine 2009;26:102-7.
13. Seers K, Carroll D. Relaxation techniques for acute pain management: a systematic review. J Adv Nurs 1998:27:466-75.

14. Yung PM, Fung MY, Chan TM, Lau BW. Relaxation training methods for nurse managers in Hong Kong: a controlled study. Int J Ment Health Nurs 2004;13:255-61.

15. Eliopoulos C. Complementary and alternative healing. In: Cherry B, Jacob SR, Eds. Contemporary Nursing: Issues, Trends \& Management. 6th ed. USA: Elsevier Mosby; 2014:204-20.

16. Cheung YL, Molassiotis A, Chang AM. A pilot study of the effect of proggressive muscle relaxation training on patients after stoma surgery. Eur J Cancer Care (Engl) 2001;10:107-14.

17. Kuzeyli Yıldııım Y, Fadıloğlu Ç. To examıne the impact of the progressive relaxation methods on anxiety levels and quality of life in dialysis patients. Journal of Ege University Nursing Faculty 2005;21:33-45.

18. Arakawa S. Relaxation to reduce nausea, vomiting, and anxiety induced by chemotherapy in Japanese patient. Cancer Nurs 1997;20:342-9.

19. Weber S. The effects of relaxation exercises on anxiety levels in psychiatric inpatients. J Holist Nurs 1996;14:196205.

20. Wilk C, Turkoski B. Progressive muscle relaxation in cardiac rehabilitation: a pilot study. Rehabil Nurs 2001;26:238-42; discussion 243.

21. Rasid ZM, Parish TS. The effects of two types of relaxation training on students' level of anxiety. Adolescence 1998;33:99101.

22. Öner N, Le Compte A. Handbook of the State-Trate Anxiety Inventory. 2nd ed. Boğaziçi University Publications. Istanbul; 1998.

23. The Turkish Psychological Association' Relaxation Exercises CD, Ankara, 2002.

24. Fujii $Y$, Toyooka $H$, Tanaka $H$. Cardiovascular responses to tracheal extubation or LMA removal in normotensive and hypertensive patients. Can J Anaesth 1997;44:1082-6.

25. Saghaei M, Razavi S. Bloodletting acupuncture for the prevention of stridor in children after tracheal extubation: a randomised, controlled study. Anaesthesia 2001;56:961-4.

26. Broillette G, Drolet P, Donati F. Deep extubation and insertion of laryngeal mask airway reduces coughing at emergence. Can $J$ Anaesth 2008;55:4721391-2.

27. Jaensson M, Olowsson LL, Nilsson $U$. Endotracheal tube size and sore throat following surgery: a randomizedcontrolled study. Acta Anaesthesiol Scand 2010;54:147-53. Epub 2009 Nov 23.

28. Turkstra TP, Smitheram AK, Alabdulhadi $\mathrm{O}$, Youssef $\mathrm{H}$, Jones PM. The FlexTipTM tracheal tube does not reduce the incidence of postoperative sore throat: a randomized controlled trial. Can J Anaesth 2011;58:1090-6. Epub 2011 Nov 5.

29. Gelinas C, Arbour C. Pain and pain management. In: Cherry B, Jacob SR, Eds. Contemporary Nursing: Issues, Trends \& Management. 6th ed. USA: Elsevier Mosby; 2014:143-67.

30. Elizabeth Joy F, Treesa Jose T, Nayak AK Effectiveness of Jacobson's progressive muscle relaxation (JPMR) technique on social anxiety among high school adolescents in a selected school of Udupi District, Kaarnataka State. NUJHS 2014;4:86-90.

31. Chaudhuri A, Ray M, Saldanha $D_{\text {, }}$ Bandopadhyay AK. Cardio-respiratory response of young adult Indian male subjects to stress: effects of progressive muscle relaxation. Medical Journal of Dr. D.Y. Patil University 2014;7:304-8.

32. Büyükyılmaz $F$, Aştı T. The Effect of Relaxation Techniques and Back Massage on Pain and Anxiety in Turkish Total Hip or Knee Arthroplasty Patients. Pain Manag Nurs 2013;14:143-54.

33. Hann Y, Ro YJ, Song HH, Kim NC, Kim $H$. The effect of thermal biofeedback and progressive muscle relaxation training in reducing blood pressure of patients with essential hypertension. Image J Nurs Sch 1993;25:204-7.

34. Yucha CB, Tsai PS, Calderon KS, Tian L. Biofeedback-assisted relaxation training for essential hypertension: who is most likely to benefit? J Cardiovasc Nurs 2005;20:198-205.

35. Najafian J, Hashemi SMG. A study of the effect of relaxation and biofeedbackassisted relaxation on patients with mild hypertension. ARYA Journal 2006;1:17882.

36. Gedik A. Assessment of preoperative and postoperative anxiety levels of neurosurgery patients (thesis). Halic University; 2015.

37. Wetsch WA, Pircher I, Lederer W, Kinzl JF, Traweger C, Heinz-Erian $P_{\text {, et }}$ al. Preoperative stress and anxiety in daycare patients and inpatients undergoing fast-track surgery. $\mathrm{Br} J$ Anaesth 2009;103:199-205.

38. Cheung YL, Molassiotis A, Chang AM. The effect of progressive muscle 
relaxation training on anxiety and quality of life after stoma surgery in colorectal cancer patients. Psychooncology 2003;12:254-66.

39. Jorm AF, Christensen $H$, Griffiths $K M$, Parslow PA, Rodgers B, Blewitt KA. Effectiveness of complementary and self-help treatments for anxiety disorders. Med J Aust 2004;181(7 Suppl):S29-46.

40. Roykulcharoen V, Good M. Systematic relaxation to relieve postoperative pain. J Adv Nurs 2004;48:140-8.

41. Bastani F, Hidarnia A, Kazemnejad A, Vafaei M, Kashanian M. A randomized controlled trial of the effects of applied relaxation training on reducing anxiety and perceived stress in pregnant women. J Midwifery Womens Health 2005;50:e36-40.

42. Yoo HJ, Ahn SH, Kim SB, Kim WK, Han OS. Efficacy of progressive muscle relaxation training and guided imagery in reducing chemotherapy side effects in patients with breast cancer and in improving their quality of life. Support Care Cancer 2005;13:826-33.

43. Bommareddi P, Valsaraj BP. Jacobson's progressive muscle relaxation training to reduce anxiety and depression among people living with HIV. NUJHS 2014;4:728.

44. Dehdari T, Heidarnia A, Ramezankhani A, Sadeghian S, Ghofranipour F. Effects of progressive muscular relaxation training on quality of life in anxious patients after coronary artery bypass graft surgery. Indian J Med Res 2009;129:603-8.

45. St.Andre AC, DelRossi A. Hemodynamic management of patients in the first 24 hours after cardiac surgery. Crit Care Med 2005;33:2082-93.

46. Roekaerts PMHJ, Heijmans JH. (2012). Early Postoperative Care After Cardiac Surgery, Perioperative Considerations in Cardiac Surgery. ISBN: 978-953-51-01475, InTech, DOI: 10.5772/27516. Available form: http://www.intechopen.com/ books/perioperative-considerations-incardiac-surgery/-early-postoperative-careafter-cardiac-surgery- Accessed October 10, 2015. 